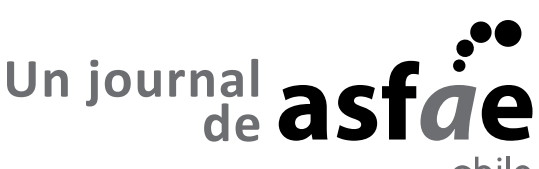

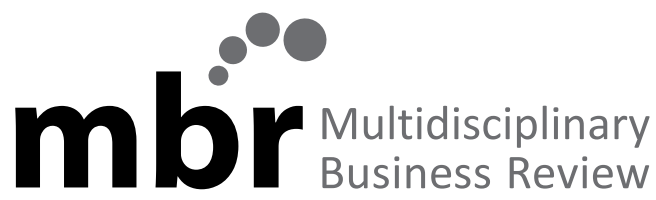

\section{ENTREPRENEURIAL ORIENTATION IN COWORKING-SPACES FOR CORPORATE ENTREPRENEURSHIP AND VENTURING}

\author{
ORIENTACIÓN EMPRENDEDORA EN ESPACIOS DE COWORKING PARA EL \\ EMPRENDIMIENTO CORPORATIVO Y EL VENTURING
}

\author{
Ricarda B. Bouncken ${ }^{\mathrm{a}}$ Lars Görmar ${ }^{\mathrm{b}}$ \\ Classification: Empirical paper - case study \\ Received: April 22, 2020 / Revised: September 7, 2020 / Accepted: November 14, 2020
}

\begin{abstract}
Firms search for new ways of improving their innovativeness and internal entrepreneurship. Entrepreneurial orientation has been shown to be a powerful facilitator for these tasks. Previous research has shown that entrepreneurial orientation increases by empowerment and proper leadership, yet we know little about the spaces in which it proliferates. We argue that social interaction and autonomy, as prevalent in coworking-spaces, strengthens and complements entrepreneurial orientation. Following the literature on entrepreneurial orientation, as well as coworking-spaces, we pursue a multiple case study analysis. We find that the elements of entrepreneurial orientation as outset by previous studies does not fully describe the entrepreneurial orientation in corporate coworking-spaces. Our findings stress that corporate entrepreneurship research and practice needs to pay more attention to the spatial and interior settings for improving innovativeness and internal entrepreneurship.
\end{abstract}

Keywords: Entrepreneurial orientation, entrepreneurship, coworking, case study

\section{Resumen}

Las empresas buscan nuevas formas de mejorar su capacidad de innovación y su espíritu empresarial interno. La orientación emprendedora ha demostrado ser un poderoso facilitador para estas tareas. Investigaciones anteriores han demostrado que la orientación emprendedora aumenta con el empoderamiento y el liderazgo adecuado, sin embargo, sabemos poco sobre los espacios en los que prolifera. Argumentamos que la interacción social y la autonomía, como prevalecen en los espacios de coworking, fortalecen y complementan la orientación empresarial. Siguiendo la literatura sobre la orientación emprendedora, así como los espacios de trabajo compartido, perseguimos un análisis de estudios de casos múltiples. Descubrimos que los elementos de la orientación emprendedora, como se inició en estudios previos, no describen completamente la orientación emprendedora en los espacios de coworking corporativos. Nuestros hallazgos enfatizan que la investigación y la práctica del espíritu empresarial deben prestar más atención a los entornos espaciales e interiores para mejorar la innovación y el espíritu empresarial interno.

Palabras clave: orientación emprendedora, emprendimiento, trabajo colaborativo, caso de estudio

a University of Bayreuth. Bayreuth, Germany. Universitätsstraße 30. Bayreuth. Email: bouncken@uni-bayreuth.de

b University of Bayreuth. Bayreuth, Germany. Universitätsstraße 30. Bayreuth. Email: lars.goermar@uni-bayreuth.de 


\section{Introduction}

Corporate entrepreneurship describes what firms do in terms of internal and external venturing (Block \& MacMillan, 1993; Glinyanova et al., 2020). It covers intrapreneurship (Pinchot, 1985), internal or intra-corporate entrepreneurship (Jones \& Butler, 1992), new business venturing (Stopford \& Baden-Fuller, 1994), venturing (Hornsby et al., 1993), and strategic entrepreneurship (Ireland et al., 2003). A key concept for those activities is the entrepreneurship orientation (EO) of or in firms that can be exposed by its managers, subordinates in units and teams (Covin et al., 2020; Hughes et al., 2018). EO is defined as "an organizational attribute that exists to the degree to which that organization supports and exhibits a sustained pattern of entrepreneurial behaviour, reflecting incidents of proactive new entry" (Covin \& Wales, 2019 , p. 3). EO research has investigated its outcomes, its forms, its corporate and its individual personality antecedents, yet is has ignored the spatial aspect of where and how EO happens.

The recent trend of coworking-spaces gives rise to this question. Initially developed in the Silicon Valley for freelancers and start-ups, coworking-spaces offer a physical space for breeding innovative ideas (Bouncken et al., 2020a; Fuzi, 2015; Gandini, 2015). The first, and still the majority, of coworking-spaces operate as shared offices with infrastructure that support freelancers and startups (Gandini, 2015). Coworking-spaces are regarded as workplaces (Gandini, 2015) that are flexible and rentable with a strong focus on the community (Fuzi, 2015). Overall, coworking-spaces are likely to support firm entrepreneurial activities (Bouncken \& Reuschl, 2018; Fuzi, 2015) by social interaction and empowerment of employees (Bouncken et al., 2020c). Assuming that firm innovativeness is mainly driven by its entrepreneurial orientation which is characterized by innovativeness, proactiveness and risk-taking behaviour (Covin \& Slevin, 1991; Covin \& Slevin, 1989; Miller, 1983), coworking-spaces are important means to enhance a firm's competitiveness. This is particularly because entrepreneurial orientation greatly influences the overall long-time well-being of a company and its performance (Madsen, 2007). Thus, 'corporates' - established firms - are starting to take upon the idea of (independent) coworking-spaces and use other spaces to implement it in their venues (Bouncken et al. 2020d; Bouncken \& Reuschl, 2018; Tracey et al., 2011).

However, the question is how does corporate entrepreneurship occur in coworking-spaces? More specifically, how do corporate coworking-spaces align with and foster entrepreneurial orientation? Considering that the design of the space and the vibe of the social interaction are core to coworking-spaces, these questions requires considering features of the coworking-space and how they trigger the entrepreneurial orientation of corporate employees located in the space.

Hence, the purpose of the current study is to study how entrepreneurial orientation materializes and what factors help firms to flourish entrepreneurial orientation in a dedicated open and entrepreneurship orientated space. Considering the knowledge void on coworking-spaces and their influence on entrepreneurial orientation in corporate firms, we employed a qualitative, deductive research approach. A qualitative research design is suitable for complex research settings with little knowledge on the investigated topic (Graebner et al., 2012). We uncover determinants of entrepreneurial orientation in corporate coworking-spaces and explain the mechanisms that determine entrepreneurial orientation in this research context.

We contribute to EO and coworking-space literatures. To the former, we contribute material and special elements. First, we show that entrepreneurial orientation experienced in new forms of organizations is based on factors other than those suggested in the established literature (e.g. Lumpkin \& Dess, 1996b; Rauch et al., 2009). Second, we show that the established elements describing entrepreneurial orientation do not fit new organizational forms such as coworking-spaces. To coworking-space research (Bouncken et al., 2020c; Bouncken et al., 2020e; Orel, 2019; Waters-Lynch \& Duff, 2019;), we contribute a theoretical foundation in corporate entrepreneurship research which has been lacking so far. Our research has managerial implications, stressing that incumbents need to be aware of new and different factors for designing their work environment and their working habits in order to enable entrepreneurial orientation in their company.

\section{Theoretical Background}

\section{Corporate Entrepreneurship and Entrepreneurship Orientation}

The last decades showed a large rise in corporate entrepreneurship (Glinyanova et al., 2020) that pertains to intrapreneurship (Pinchot, 1985) and institutional entrepreneurship (Block \& MacMillan, 1993; Glinyanova et al., 2020; Tiberius et al., 2020). It covers intrapreneurship (Pinchot, 1985), internal or intra-corporate entrepreneurship (Jones \& Butler, 1992), new business venturing (Stopford \& Baden-Fuller, 1994), venturing (Hornsby et al., 1993), strategic entrepreneurship (Ireland et al., 2003), internal or intra-corporate entrepreneurship (Jones \& Butler, 1992), new business venturing (Stopford \& Baden-Fuller, 1994), venturing (Hornsby et al., 1993), and strategic entrepreneurship (Ireland et al., 2003). Entrepreneurial orientation describes antecedents 
of the entrepreneurial processes on a company-level as opposed to the innovativeness of a dominant person in the company (Miller, 1983; Covin et al., 2020; Hughes et al., 2018). With this, entrepreneurial orientation is the thrive towards new entries (Lumpkin \& Dess, 1996b). A new entry can be achieved "by entering new or established markets with new or existing goods or services" (Lumpkin \& Dess, 1996b, p. 136). It can furthermore be any kind of venturing activity. The first prominent five dimensions (Lumpkin \& Dess, 1996b) were later often reduced to three dimensions: innovativeness, proactiveness, and risk-taking (Covin \& Lumpkin, 2011; Covin \& Miller, 2014; Rauch et al., 2009). Innovativeness is the basis of engaging in creating and developing processes, e.g. through introducing new products and services to gain technological leadership (Lumpkin \& Dess, 1996b; Rauch et al., 2009). Proactiveness describes the activeness of a company to introduce new products or services as action rather than reaction and anticipating future developments (Lumpkin \& Dess, 1996b; Rauch et al., 2009). Risk-taking means the inclination to take uncertain opportunities and chances such as dicey venturing activities or significant resource allocations to uncertain projects (Lumpkin \& Dess, 1996b; Rauch et al., 2009).

The establishing construct (Martens et al., 2016) applied in various studies (Anderson et al., 2004; George \& Marino, 2011), shows that there is anecdotal as well as empirical evidence for the positive impact of entrepreneurial orientation on a firm's performance. Researchers found that strong entrepreneurial orientation leads to higher business performance (Vij \& Bedi, 2012), eventually proving that entrepreneurial orientation positively influences company performance (Fellnhofer et al., 2016; Pearce et al. 2010; Rauch et al., 2009).

As initially stated by Miller (1983), entrepreneurial orientation is a construct of strategic nature. By evaluating innovativeness, proactiveness, and risk-taking, it evaluates how entrepreneurial companies are in their strategic posture (Covin \& Slevin, 1989). Consequently, entrepreneurial orientation is a core element of strategic renewal, and research shows that strategic renewal is important for constant company success (Agarwal \& Helfat, 2009). In order to survive in the global business context, established firms need to apply entrepreneurial strategies (McGrath \& MacMillan, 2000; Morris et al., 2008). These entrepreneurial strategies propose ideas to revive current organizations and improve the innovativeness (Cooper et al., 2000). Consequently, the outcomes that Amit et al., (2000) observed - that is "entrepreneurial strategies allow people to be innovative, creative, and responsible for decisions that they make" - are highly desirable (Ireland et al., 2009, p.19).
Following Covin \& Slevin (1989), companies that are considered entrepreneurial employ managers with high entrepreneurial skills and this spills over into strategic decisions and the operating management. Additionally, mentality and behaviour are analogous to the prospector firms from Miles \& Snow (1978) and the entrepreneurial organizations from Mintzberg (1973). Today's examples of these categories are young, dynamic start-ups, such as innovative companies like Google or Facebook. The latest element that supports entrepreneurship in all its facets are the recently mushrooming coworking-spaces (Fuzi, 2015). While several antecedents, moderators, and outcomes of EO have been reported, we still face an almost complete knowledge void on the spatial component of EO and corporate entrepreneurship. Still, the void is most prevalent given the coworking-space trend that has arisen in the past few years (Bouncken et al., 2020b; Bouncken et al., 2020e; Hughes et al., 2018).

\section{Coworking-Spaces}

Coworking-spaces are regarded as shared workplaces that combine the necessary infrastructure as well as the social surroundings for work, especially the digital facilities (Bouncken \& Reuschl, 2017). The provider usually offers workspaces with desks and IT-infrastructure as well as a social space for social interaction. Regarding the infrastructure, coworking-spaces often provide conference rooms, a kitchen, a lounge or a cafeteria, and fully equipped work-shops (Bouncken \& Reuschl, 2018). Regarding the surroundings, they offer social spaces and many opportunities for their users to communicate (Capdevila, 2013). The sense of community and the community itself are an important means to foster creativity (Fuzi, 2015) and to enhance innovativeness (Greenwood et al., 2010).

Additionally, having pre-selected likeminded colleagues increases the chance for valuable cooperation and alliances, while supporting business model innovation activities (Bouncken \& Fredrich, 2016; Bouncken, Kraus, Roig-Tierno, 2019). This reciprocal support and interaction further help young, developing ventures to gain and establish legitimacy in the market (Täuscher et al., 2020). In combination with regular feedback from peers and open collaboration, these factors improve the work results as well as innovativeness in coworkingspaces (Hughes et al., 2018). Enhancing innovativeness is also of relevance for established firms which have recently started to apply the coworking-aspect in order to create a creative environment (Tracey et al., 2011) - so-called corporate coworking-spaces. Furthermore, coworking-spaces bring people together, allowing to 
create a shared identity (Bouncken \& Barwinski, 2020). Users of coworking-spaces are likeminded co-workers (Spinuzzi, 2012) who often build a sense of community (Moriset, 2014). Coworking-spaces allow independent and temporary work, as well as new spaces for incumbent firms to foster fluidity, flexibility, and innovation (Bouncken \& Kraus, 2013). Recognizing the common grounds and acknowledging them is the most important step for creating a vivid community (Waters-Lynch $\&$ Duff, 2019). This allows them to better combine and exploit existing knowledge (Bouncken et al., 2018c) and assess the full potential of their employees (Bouncken \& Aslam, 2019).

The corona-pandemic, during 2020, showed that remote work such as 'working from home' is possible for a broad part of the workforce; however, people miss social interaction. Since coworking-spaces offer, not only a place to work, but with their communityconcepts also a place for social interaction, the concept of coworking-spaces eventually increases work satisfaction (Bouncken et al., 2020c).

In the context of coworking-spaces, innovative activities play a crucial role for the users of coworking-spaces (Bouncken \& Reuschl, 2018). Co-workers pursue, not only their daily business, but they also want to develop new business ideas or work on innovative ideas (Barwinski et al., 2020; Bouncken et al., 2020b; Görmar et al., 2020), especially since start-ups and entrepreneurs use coworking-spaces as breeding-places for their new ideas (Fuzi, 2015; Gandini, 2015). Co-workers with their start-ups want to disrupt the current marketsituation. They think differently, apply new methods and approach problems in innovative ways. For this to happen, entrepreneurial orientation is an important factor or outcome of individuals working in coworking-spaces and the coworking-space environment as a whole.

\section{Methodology}

\section{Research Design}

Currently, there is not much information about organization in coworking-spaces, especially in corporate venues and the intersection with the entrepreneurial orientation of firms. For our research target that relates to little pre-existing knowledge, we chose the qualitative case study design suggested by Eisenhardt (1989). A case study is the most suited research method of choice when facing a rather new topic and focusing on a holistic view (Feagin et al., 1991). A multiple case study approach not only allows for the gathering of rich, in-depth data (Anteby et al., 2015; Bluhm et al., 2011; Yin,
2009), but also enables the analysis of causal relations (Gartner \& Birley, 2002). Additionally, a case study approach allows us to consider context information and, in turn, explain and transport a theory (Welch et al., 2011). This approach allows augmenting an established theory rather than establishing a new one. Since we do not focus on the development of a theory but want to advance and enhance an existing theory, we systematically combine theoretical framework development, empirical fieldwork, and case study analysis (Dubois \& Gadde, 2002). Systematic combining focuses on theory development as opposed to grounded theory (Glaser, 1992; Glaser \& Strauss, 1967) which emphasizes the data collection process and discovering theory without considering existing research while doing so (Eisenhardt \& Graebner, 2007; Langley, 1999). The method is widely accepted and has been applied in various articles on systematic combing (e.g. Erkama \& Vaara, 2010; Edvardsson et al., 2008). By combining theoretical framework development, empirical fieldwork, and case study analysis, we pursue a reiterative process. This allows for a unique way of integrating new empirical insights and established research.

\section{Sample}

In our multiple case study, we analyse 18 different company offices, which have organized their office in a coworking-space style and are located in major cities in Germany. These companies are a very good example of companies trying to change from a traditional to a coworking-space setting for several reasons: 1) The companies started their change-process between 12 and 24 months before our interview, making them knowledgeable in both a normal company structure as well as the coworking structure. 2) The companies are working in the initial coworking-branches, the IT-industry and the creative-industry. 3) All companies were still in the start-up phase, with none being older than two years and all of them being younger than five years. Our multiple case study is based on a careful document analysis for each of the 18 companies and interviews with providers of the coworking-space, represented by managers, and with coworking-space users, represented by employees from each company. In total, we analysed $21 \mathrm{~h} 39$ minutes of interview from providers and 26h 56 minutes interview from users (table 1). By integrating both perspectives, we were able to improve data quality in our study and gain valuable new insights.

As we had already identified literature related to our research topic, we did not follow a grounded theory approach. Instead we used the Gioia methodology (Gioia et al., 2013), which is a prior-informed approach 
Table 1. Description of Dataset

\begin{tabular}{|c|c|c|c|}
\hline $\begin{array}{c}\begin{array}{c}\text { Coworking- } \\
\text { Space }\end{array} \\
\end{array}$ & City & $\begin{array}{l}\text { Provider } \\
\text { Interview }\end{array}$ & User Interview \\
\hline CWS-1 & Munich & 58 Minutes & 1h 27 minutes \\
\hline CWS-2 & Berlin & 1h 13 minutes & 1h 20 minutes \\
\hline CWS-3 & Berlin & 1h 1 minute & 1h 30 minutes \\
\hline CWS-4 & Berlin & 59 minutes & 1h 31 minutes \\
\hline CWS-5 & Munich & 1h 27 minutes & 1h 29 minutes \\
\hline CWS-6 & Munich & 1h 25 minutes & 1h 33 minutes \\
\hline CWS-7 & Munich & 1h 28 minutes & 1h 36 minutes \\
\hline CWS-8 & Hamburg & 1h 19 minutes & 1h 22 minutes \\
\hline CWS-9 & Hamburg & 1h 12 minutes & 1h 29 minutes \\
\hline CWS-10 & Frankfurt & 1h 15 minutes & 1h 25 minutes \\
\hline CWS-11 & Frankfurt & 1h 2 minutes & 1h 34 minutes \\
\hline CWS-12 & Munich & 58 minutes & 1h 31 minutes \\
\hline CWS-13 & Berlin & 1h 12 minutes & 1h 26 minutes \\
\hline CWS-14 & Frankfurt & 1h 18 minutes & 1h 32 minutes \\
\hline CWS-15 & Hamburg & 1h 22 minutes & 1h 38 minutes \\
\hline CWS-16 & Frankfurt & 1h 16 minutes & 1h 19 minutes \\
\hline CWS-17 & Munich & 1h 13 minutes & 1h 30 minutes \\
\hline CWS-18 & Berlin & $1 \mathrm{~h}$ & 1h 34 minutes \\
\hline TOTAL & & 21h 39 minutes & $26 \mathrm{~h} 56$ minutes \\
\hline Average & & 1h 12 minutes & 1h 29 minutes \\
\hline
\end{tabular}

suggesting a step-wise coding process from broad concepts found in the interviews over abstract themes to aggregated dimensions (Strauss \& Corbin, 1998). By first looking for mutual themes and topics that the interviewees mentioned and talked about, we developed first order concepts. In the next step, these concepts are aggregated to second order constructs and finally to an aggregate dimension.

\section{Data Collection}

Data was collected from March 2019 to May 2019. It mainly consisted of archival data such as company websites, annual reports, social media and press coverage. Based on the archival data, the literature, and the prior data analysis, we developed semi-structured interview-guidelines (Yin, 2009). The interviews were carried out between May 2019 and September 2019. The interviews took place at the company offices and were conducted face to face by two researchers, recorded and carefully transcribed on the same day. The transcripts were sent to the interview partner to be checked and approved.

\section{Data Analysis}

The approach of systematic combining requires abductive logic to combine both deductive and inductive arguments (Durand \& Vaara, 2009). First, we viewed, aggregated, and merged interview material, literature, and additional secondary data. Inconsistencies were clarified by additional research and queries with the interviewees. We then coded all information following the Gioia methodology (Gioia et al., 2013). Two researchers applied the methodology independently and coded the first order concepts. While discussing the results, the researchers found no differences in the understanding of the collected material.

\section{Findings}

Our findings are aggregated in table 2. In the following, we would like to explain in more detail how we arrived at these findings, with focus on the three steps: 1) first order concepts, 2) second order themes, and 3) aggregate dimension.

On one hand, we found in the interviews that the interviewees organize their work mostly on their own. Working on your own tasks, whenever and wherever you want was not only mentioned very often in different ways, but was also valued by the people surveyed (CWS-3: "We really do have a lot of freedom regards to our tasks, and for many people that is an important aspect of our work here."). Additionally, this freedom also materializes in the interaction of employees with employers. For this, the companies have established ways for the employees to participate in the development and design of the company (CWS-17: "When we have ideas for improving processes or whatever at the company, we are highly welcome to communicate those ideas. And if it makes sense, often the initiator is in charge of implementing the improvement without having long and big meetings beforehand."). Furthermore, own projects for the company are encouraged. In combination with a familial environment and employee-development this helps the employees feel like they are part of the company and feel valued (CWS-8: We feel at home here, the employer values everyone. We get additional training and when we have good ideas, we can pursue them for the company."). We combined those elements to the aggregate dimension Proactiveness (table 2) because they describe the encouragement of the employees towards self-organized, self-motivated, and actively participating members.

On the other hand, respondents mentioned the open atmosphere. The respondents can talk to each other and learn tremendously. Talking to other employees they would usually not see improves their knowledge. 
The open office concept is a necessity for that and supports the behaviour (CWS-18: "Everything here is aimed at knowledge exchange. The office structure really helps us talk to everyone about everything which really seems to help access all available knowledge"). Additionally, the company takes all means to access relevant knowledge. Not only do they include employees in development and decision-making processes, but they also include the customers in the creating processes by accessing their knowledge (CWS-5: "We at [company_name] really try everything to access knowledge. Be it employees, users, whoever we can find to learn from, we do it. And we try to use the knowledge [...]".). We combined these aspects to the aggregate dimension Innovativeness (table 2) because combining existing knowledge and exploiting existing knowledge are elements that describe and improve the innovation dimension.

Concluding, our findings show that with innovativeness and proactiveness the descriptions of the corporate coworking-spaces largely reflect the elements of entrepreneurial orientation (see table 2). The innovativeness is mostly prevalent through the recombination of knowledge and exploiting existing knowledge. The element of proactiveness is diverse and subliminal, existing in manifold ways. Surprisingly, in our sample, no interviewee mentioned indicators for risk-taking.

\section{Discussion}

This study set out to analyse the spatial dimension of corporate entrepreneurship by analysing how EO occurs in coworking-spaces. We find that entrepreneurial orientation in corporate coworking-spaces materializes through proactiveness and innovativeness, but not through increased risk taking. In the latter, we contrast the established literature (Lumpkin \& Dess, 1996a; Rauch et al., 2009). We then highlight that proactiveness in coworking-spaces is characterized by self-organization, structures for participation and structures for integration rather than by activeness to introduce new products or services. These findings support existing research. Additionally, we show that innovativeness materializes through the recombination of knowledge and through exploiting existing knowledge, rather than through the temper of engaging in creation and developing processes.

Based on traditional entrepreneurial orientation literature, we describe proactiveness as the activeness of a company to introduce new products or services as action

Table 2. Analytical Coding Process to Describe the New Entrepreneurial Orientation

\begin{tabular}{|c|c|c|}
\hline 1st order concepts & 2nd order themes & Aggregate dimensions \\
\hline - Within borders: free choice of task & & \multirow{10}{*}{ Proactiveness } \\
\hline - Flexible access to the office and flexible working hours & Self-organized work & \\
\hline - Within borders: high autonomy in place of work & & \\
\hline - Employees are encouraged to suggest improvements & & \\
\hline - Low hierarchical structures & Structures for enabling participation of employees & \\
\hline - Short decision processes & & \\
\hline - Training off/on/near the job & \multirow{4}{*}{ Making the employees a part of the whole } & \\
\hline - Own (risky) project ideas are encouraged & & \\
\hline - Considering themselves as friends/family, not company & & \\
\hline - New collaborations based on employees' networks & & \\
\hline - Open office concepts free the mind & \multirow{4}{*}{ Recombination of knowledge } & \multirow{8}{*}{ Innovativeness } \\
\hline - Exchange of knowledge with other people & & \\
\hline - Seat different teams/functions together & & \\
\hline - Diverse knowledge/educational/functional background & & \\
\hline - Employee participation in development & \multirow{4}{*}{ Exploiting existing knowledge } & \\
\hline - Involve the customers of tomorrow & & \\
\hline - Involve employees in decision making & & \\
\hline - Broader events for networking & & \\
\hline
\end{tabular}


rather than reaction by anticipating future developments (Lumpkin \& Dess, 1996a; Rauch et al., 2009). However, our results draw a different picture, putting the (1) individual organization, the (2) individual participation, and the (3) individual integration in the centre. (1) Employees have more freedom in their work disposition (i.e. choice of task, flexible office hours, and flexible workplace) but are supposed to make good use of it. Employees are provided with greater autonomy to make better use of their resources and capabilities. These advantages enfold under the premise that everyone is actively taking upon this freedom and working with it. (2) Additionally, employees have more possibilities to actively participate by suggesting improvements in their own processes and structures in the low hierarchical environment and by participating in the short and direct decision process. This element describes the individual proactiveness. Employees are supposed to use the organizational structure for influencing the company in a way they want. (3) Lastly, proactiveness demands actively integrating in the social environment. Employees shall be friends with their co-workers and consider the workplace rather as a place for fun, fulfilment and personal development than a place for strict and serious work. Competition can be a danger in coworking-spaces but should not come with relational conflict (Bouncken et al., 2018c; Waters-Lynch \& Duff, 2019). This attaches the employees to the company and its well-being, encouraging them to always do their best.

Next, we conceptualize innovativeness as a basic driver of engaging in creating and developing processes, e.g. through introducing new products and services to gain technological leadership (Lumpkin \& Dess, 1996a; Rauch et al., 2009). We portray a partly different perception of innovativeness than in the prior literature (Covin et al., 2020). In our sample, (1) the recombination of knowledge and (2) the exploitation of existing knowledge are core aspects, rather than creativity and developing itself. (1) Recombining knowledge is possible by better access to everyone's knowledge. The non-existence of build-in boundaries but instead of open office concepts and the regular exchange with different people in coworking-spaces improves the knowledge flow and enables the knowledge recombination. (2) The exploitation of the existing knowledge by integrating future customers and by exploiting knowledge from outsiders allows for drawing on more diverse aspects, which eventually enables innovativeness.

Surprisingly, we did not find indications of increased risk-taking behaviour in coworking-spaces. A reason for this might be that most employees still perceive the risk to be for the company's owner or the construct "company". The employees seem to evaluate aspects that are considered risky rather than chances for their own participation or self-fulfilment and thus labelling them as individual participation. Furthermore, aspects like risky projects from individuals were mentioned as enabling proactiveness and not seen as corporate risk-taking.

Our findings point towards the notion that entrepreneurial orientation is much more than an orientation or mental mindset, influenced by leadership or empowerment. Firms can create physical places that support an entrepreneurial mindset. Within this physical space, it is not only the infrastructure that fosters entrepreneurial orientation, but the social interaction. The interplay between social aspects and material infrastructure, the socio-materiality, greatly improves the entrepreneurial situation for co-workers (Bouncken et al., 2020e) making the social space an important multiplier of entrepreneurial activities. In this context, entrepreneurial orientation can develop dynamically.

Our findings show that coworking-spaces influence the work regarding social effects such as overcoming social isolation (Moriset, 2014) and offering a likeminded community (Bouncken \& Reuschl, 2018). Coworking-spaces have developed into places where entrepreneurial orientation potential is nurtured and fostered. Coworking-spaces are place for social interaction and offer a workplace with higher work satisfaction, but furthermore, they are a place for enabling the necessary mindset for innovation. Additionally, Bergman \& McMullen (2020) found that providers of coworking-spaces and especially of makerspaces need to consider six questions for designing their space. The six questions address social and member-related aspects as well as physical space designing aspects, showing that socio-materiality is important for everyone's success. When coworking-spaces are not well planned or managed, they allow the self-interest of their users and facilitate 'dark traits' (Bouncken et al., 2018a).

Although it is widely accepted that co-workers (mostly) pursue innovative and entrepreneurial activities regarding our today's understanding, our data shows that based on traditional concepts like the entrepreneurial orientation, co-workers indeed have an entrepreneurial mindset and a set of values. Furthermore, it enhances the view of the latest findings on entrepreneurship in coworking-spaces (Bouncken et al. 2020f).

In sum, our results show that entrepreneurial orientation in corporate coworking-spaces brings a new facet to corporate entrepreneurship (Glinyanova et al., 2020). The dimensions of entrepreneurial orientation mostly still apply in the new spatial organizational context, but the materialization differs tremendously. In this study, we focused on independent coworking-spaces and the transfer of elements of the entrepreneurial orientation towards 
corporate coworking-spaces. However, there are four different types of coworking-spaces (Bouncken et al., 2017): besides (1) independent coworking-spaces, and (2) corporate coworking-spaces, there are also (3) open corporate coworking-spaces, and (4) consultancy coworking-spaces. While corporate coworking-spaces offer an innovative office structure for employees, open corporate coworking-spaces also allow external people to rent desks in the space. Accordingly, the spaces might supply and integrate short-term external knowledge and additional new possibilities for entrepreneurial orientation to develop within the corporate context. The consultancy coworking-space is often configured as a 'sandbox'. The combination of permanent staff with internal and external experts, allows consultancies to offer their coworkingconcept to foster innovation by also considering coopetition (Bouncken et al., 2018b; Bouncken \& Fredrich, 2016). Following an earlier suggestion of Bouncken (2018), there is a fifth category, the university coworking-spaces. Universities develop parts of already existing libraries for university coworking-spaces. In combination with entrepreneurship classes, students get the best opportunities for founding their own businesses.

Our findings allow several implications on both the research and practical level. For researchers our findings imply that entrepreneurial orientation is different than it used to be. The new elements of entrepreneurial orientation and new ways of materialization in the context of new work forms require more research for a deeper understanding of the new entrepreneurial orientation. The findings allow the assumption that the concept of entrepreneurial orientation has shifted from an established, well-known concept towards a new one. The detailed configurations of this new concept need to be further investigated. On a practical level, our findings call for a change in the design of work environments and working habits. Since entrepreneurial orientation is now described by other factors that materialize in new and different ways than those recognised by established research, companies need to adapt to these new factors and elements. This is important in order to enable entrepreneurial orientation in companies. Eventually, this leads to a new set of measures or actions that companies need to activate in order to maintain the entrepreneurial orientation and, in turn, their long-term competitiveness.

\section{Conclusion}

Based on the literature regarding entrepreneurial orientation and coworking-spaces, we investigated the driving factors of entrepreneurial orientation in corporate coworking-spaces. We analysed how corporate coworking- spaces foster entrepreneurial orientation and what features of coworking-spaces trigger the entrepreneurial orientation of corporate employees in this corporate coworking-space. We show that the entrepreneurial orientation-elements' innovativeness and proactiveness are important in corporate coworking-spaces but do need an adjustment regarding there form of materialization. This adjustment is important because relying on existing research for implementing entrepreneurial orientation in corporate coworking-spaces does not yield the pursued aims. Furthermore, we show that risk-taking is not a prevalent factor in our sample, making it somewhat less relevant for triggering entrepreneurial orientation in corporate coworking-spaces. These findings put entrepreneurial orientation in a new context, requiring researchers to investigate the materialization of entrepreneurial orientation in different environments. This is necessary for the literature to gain a more holistic view of the topic as well as the practitioners to trigger entrepreneurial orientation in employees in corporate coworking-spaces.

With this study, we contribute to the literature of entrepreneurial orientation. We show that re-thinking the elements and further developing the whole construct is necessary to describe the situation in the real world as of today. Additionally, we contribute to the literature of coworking-spaces by showing that coworking-spaces as the new era of organizational configurations change the way people perceive the work setting.

We know that literature on coworking-spaces is still scarce and that entrepreneurial orientation is a manifold research topic. Our paper represents a first insight into the new combinations of established constructs, scratching the surface of a promising research topic. For example, comparing the entrepreneurial orientation, its elements, as well as the materialization between corporate coworking-spaces and the more traditional coworking-spaces would be interesting. Enhancing knowledge on this topic in the future will improve the work-life situation especially for self-employed people and start-ups.

\section{References}

Agarwal, R., \& Helfat, C. E. (2009). Strategic renewal of organizations. Organization Science, 20(2), 281-293.

Amit, R., Brigham, K., \& Markman, G. (2000). Entrepreneurial management as strategy,[w:]. In G. D. Meyer, \& K. A. Heppard (red.), Entrepreneurship as strategy. Competing on the entrepreneurial edge. London-New Delhi.

Anderson, N., De Dreu, C. K. W., \& Nijstad, B. (2004). The routinization of innovation research: A constructively critical review of the state-of-the-science. Journal of Organizational Behavior, 25, 147-173. 
Anteby, M., Lifshitz, H., \& Tushman, M. (2015). Using qualitative research for "How" questions. Strategic Management Journal, 36(6), 3.

Barwinski, R. W., Qiu, Y., Aslam, M. M., \& Clauss, T. (2020). Changing with the time: New ventures' quest for innovation. Journal of Small Business Strategy, 1(30), 19-31.

Bergman, B. J., \& McMullen, J. S. (2020). Entrepreneurs in the making: Six decisions for fostering entrepreneurship through maker spaces. Business Horizons, 63(6), 811-824.

Block, Z., \& MacMillan, I. C. (1993). Corporate venturing: Creating new businesses within the firm. Harvard Business School Press.

Bluhm, D. J., Harman, W., Lee, T. W., \& Mitchell, T. R. (2011). Qualitative research in management: A decade of progress. Journal of Management Studies, 48(8), 1866-1891.

Bouncken, R., Reuschl, A., \& Görmar, L. (2017). Archetypes and proto-institutions of coworking-spaces: Emergence of an innovation field? Strategic Management Society Annual Conference. Houston, Texas, USA.

Bouncken, R., \& Barwinski, R. (2020). Shared digital identity and rich knowledge ties in global 3D printing-A drizzle in the clouds? Global Strategy Journal 2020, 1-28.

Bouncken, R., Cesinger, B., \& Tiberius, V. (2020a). Narcissism, machiavellianism, and psychopathy of top managers - Can entrepreneurial orientation secure performance? International Journal of Entrepreneurial Venturing, 12(3), 272-302.

Bouncken, R., Qiu, Y., \& Clauss, T. (2020b). Coworking-space business models: Micro-ecosystems and platforms - Insights from China. International Journal of Innovation \& Technology Management, 17(6), 1-21.

Bouncken, R., Ratzmann, M., Barwinski, R., \& Kraus, S. (2020c). Coworking spaces: Empowerment for entrepreneurship and innovation in the digital and sharing economy. Journal of Business Research, 114, 102-110.

Bouncken, R., Ratzmann, M., \& Kraus, S. (2020d). Anti-aging: How innovation value creation is shaped by firm age and mutual knowledge creation in an alliance. Journal of Business Research ( accepted).

Bouncken, R. B., \& Kraus, S. (2013). Innovation in knowledge-intensive industries: The double-edged sword of coopetition. Journal of Business Research, 66(10), 2060-2070.

Bouncken, R. B., Kraus, S., Roig-Tierno, N. (2019). Knowledge- and innovation-based business models for future growth: Digitalized business models and portfolio considerations. Review of Managerial Science, 1-14. Available at https://doi.org/10.1007/s11846-01900366-z.
Bouncken, R. B., \& Fredrich, V. (2016). Good fences make good neighbors? Directions and safeguards in alliances on business model innovation. Journal of Business Research, 69(11), 5196-5202.

Bouncken, R. B., \& Reuschl, A. J. (2017). Coworking-spaces: Chancen für entrepreneurship und business model design. ZfKE-Zeitschrift für KMU und Entrepreneurship, 65(3), 151-168.

Bouncken, R. B. (2018). University coworking-spaces: Mechanisms, examples, and suggestions for entrepreneurial universities. International Journal of Technology Management (IJTM), 77(Nos. 1/2/3), 38-56.

Bouncken, R. B., Aslam, M. M., \& Reuschl, A. J. (2018a). The dark side of entrepreneurship in coworking-spaces. In A. T. Porcar \& D. R. Soriano (Eds.), Inside the mind of the entrepreneur (1st ed.). Springer.

Bouncken, R. B., Fredrich, V., Ritala, P., \& Kraus, S. (2018b). Coopetition in new product development alliances: Advantages and tensions for incremental and radical innovation. British Journal of Management, 29(3), 391-410.

Bouncken, R. B., Laudien, S. M., Fredrich, V., \& Görmar, L. (2018c). Coopetition in coworking-spaces: Value creation and appropriation tensions in an entrepreneurial space. Review of Managerial Science, 12(2), 385-410.

Bouncken, R. B., \& Reuschl, A. J. (2018). Coworking-spaces: How a phenomenon of the sharing economy builds a novel trend for the workplace and for entrepreneurship. Review of Managerial Science, 12(1), 317-334.

Bouncken, R. B., \& Aslam, M. M. (2019). Understanding knowledge exchange processes among diverse users of coworking-spaces. Journal of Knowledge Management, 23(10), 2067-2085.

Bouncken, R. B., Aslam, M. M., \& Qiu, Y. (2020e). Coworking spaces: Understanding, using, and managing sociomateriality. Business Horizons, 64(1), 119-130.

Bouncken, R. B., Kraus, S., \& Martínez-Pérez, J. F. (2020f). Entrepreneurship of an institutional field: The emergence of coworking spaces for digital business models International. Entrepreneurship and Management Journal.

Capdevila, I. (2013). Typologies of localized spaces of collaborative innovation (SSRN 2414402). Social Science Research Network.

Cooper, A., Markman, G., \& Niss, G. (2000). The evolution of the eld of entrepreneurship (pp. 45-67). Sage Publishers.

Covin, J. G., \& Slevin, D. P. (1989). Strategic management of small firms in hostile and benign environments. Strategic Management Journal, 10(1), 75-87. 
Covin, J. G., \& Slevin, D. P. (1991). A conceptual model of entrepreneurship as firm behaviour. Entrepreneurship: Critical perspectives on business and management, 3, 5-28.

Covin, J. G., \& Lumpkin, G. T. (2011). Entrepreneurial orientation theory and research: Reflections on a needed construct. Entrepreneurship Theory and Practice, 35(5), 855-872.

Covin, J. G., \& Miller, D. (2014). International entrepreneurial orientation: Conceptual considerations, research themes, measurement issues, and future research directions. Entrepreneurship Theory and Practice, 38(1), 11-44.

Covin, J. G., \& Wales, W. J. (2019). Crafting high-impact entrepreneurial orientation research: Some suggested guidelines. Entrepreneurship Theory and Practice, 43(1), 3-18.

Covin, J. G., Rigtering, J., Hughes, M., Kraus, S., Cheng, C.-F., \& Bouncken, R. (2020). Individual and team entrepreneurial orientation: Scale development and configurations for success. Journal of Business Research, 112, 1-12.

Dubois, A., \& Gadde, L.-E. (2002). Systematic combining: An abductive approach to case research. Journal of Business Research, 55(7), 553-560.

Durand, R., \& Vaara, E. (2009). Causation, counterfactuals, and competitive advantage. Strategic Management Journal, 30(12), 1245-1264.

Edvardsson, B., Holmlund, M., \& Strandvik, T. (2008). Initiation of business relationships in service-dominant settings. Industrial Marketing Management, 37(3), 339-350.

Eisenhardt, K. M. (1989). Building theories from case study research. Academy of Management Review, 14(4), 532-550.

Eisenhardt, K. M., \& Graebner, M. E. (2007). Theory building from cases: Opportunities and challenges. Academy of Management Journal, 50(1), 25-32.

Erkama, N., \& Vaara, E. (2010). Struggles over legitimacy in global organizational restructuring: A rhetorical perspective on legitimation strategies and dynamics in a shutdown case. Organization Studies, 31(7), 813-839.

Feagin, J. R., Orum, A. M., \& Sjoberg, G. (1991). A case for the case study. UNC Press Books.

Fellnhofer, K., Puumalainen, K., \& Sjögrén, H. 2016. Entrepreneurial orientation and performance-Are sexes equal? International Journal of Entrepreneurial Behavior \& Research, 22(3), 346-374.

Fuzi, A. (2015). Co-working spaces for promoting entrepreneurship in sparse regions: The case of South Wales. Regional Studies, Regional Science, 2(1), 462-469.
Gandini, A. (2015). The rise of coworking spaces: A literature review. Ephemera, 15(1), 193-205.

Gartner, W. B., \& Birley, S. (2002). Introduction to the special issue on qualitative methods in entrepreneurship research. Journal of Business Venturing, 17(5), 387-395.

George, B. A., \& Marino, L. (2011). The epistemology of entrepreneurial orientation: Conceptual formation, modeling, and operationalization. Entrepreneurship Theory and Practice, 35(5), 989-1024.

Gioia, D. A., Corley, K. G., \& Hamilton, A. L. (2013). Seeking qualitative rigor in inductive research: Notes on the Gioia methodology. Organizational Research Methods, 16(1), 15-31.

Glaser, B., \& Strauss, A. (1967). The Discovery of Grounded Theory. Strategies for Qualitative Research. Aldine Publishing Company.

Glaser, B. G. (1992). Basics of grounded theory analysis: Emergence vs forcing. Sociology Press.

Glinyanova, M., Bouncken, R., Tiberius, V., \& Cuenca-Ballester, A. C. (2020). Five decades of corporate entrepreneurship research: Measuring and mapping the field. International Entrepreneurship and Management Journal (accepted).

Görmar, L., Barwinski, R., Bouncken, R., \& Laudien, S. (2020). Co-Creation in coworking-spaces: Boundary conditions of diversity. Knowledge Management Research \& Practice, 1-12.

Graebner, M. E., Martin, J. A., \& Roundy, P. T. 2012. Qualitative data: Cooking without a recipe. Strategic Organization, 10(3), 276-284.

Greenwood, R., Díaz, A. M., Li, S. X., \& Lorente, J. C. (2010). The multiplicity of institutional logics and the heterogeneity of organizational responses. Organization Science, 21(2), 521-539.

Hornsby, J. S., Naffziger, D. W., Kuratko, D. F., \& Montagno, R. V. (1993). An interactive model of the corporate entrepreneurship process. Entrepreneurship Theory and Practice, 17(2), 29-37.

Hughes, M., Rigtering, J. P. C., Covin, J. G., Bouncken, R. B., \& Kraus, S. (2018). Innovative behaviour, trust and perceived workplace performance. British Journal of Management, 29(4), 750-768.

Ireland, R. D., Hitt, M. A., \& Sirmon, D. G. (2003). A model of strategic entrepreneurship: The construct and its dimensions. Journal of Management, 29(6), 963989.

Ireland, R. D., Covin, J. G., \& Kuratko, D. F. (2009). Conceptualizing corporate entrepreneurship strategy. Entrepreneurship theory and practice, 33(1), 19-46. 
Jones, G. R., \& Butler, J. E. (1992). Managing internal corporate entrepreneurship: An agency theory perspective. Journal of Management, 18(4), 733-749.

Langley, A. (1999). Strategies for theorizing from process data. Academy of Management Review, 24(4), 691710.

Lumpkin, G. T., \& Dess, G. G. (1996a). Clarifying the entrepreneurial orientation construct and linking it to performance. Academy of Management Review, 21(1), 135-172.

Lumpkin, G. T., \& Dess, G. G. (1996b). Enriching the entrepreneurial orientation construct - Reply to "Entrepreneurial orientation or pioneer advantage". Academy of Management Review, 21(3), 605-607.

Madsen, E. L. (2007). The significance of sustained entrepreneurial orientation on performance of firms - A longitudinal analysis. Entrepreneurship and Regional Development, 19(2), 185-204.

Martens, C. D. P., Lacerda, F. M., Belfort, A. C., \& Freitas, H. M. R. d. (2016). Research on entrepreneurial orientation: Current status and future agenda. International Journal of Entrepreneurial Behavior \& Research, 22(4), 556-583.

McGrath, R. G., \& MacMillan, I. C. (2000). The entrepreneurial mindset: Strategies for continuously creating opportunity in an age of uncertainty. Harvard Business Press.

Miles, R. E., \& Snow, C. C. (1978). Organizational strategy, structure, and process. McGraw-Hill.

Miller, D. (1983). The correlates of entrepreneurship in three types of firms. Management Science, 29(7), 770 791.

Mintzberg, H. (1973). Strategy-making in three modes. California Management Review (pre-1986), 16(000002), 44.

Moriset, B. (2014). Building new places of the creative economy. The rise of coworking spaces. Paper presented at the 2nd Geography of Innovation International Conference, Utrecht.

Morris, M. H., Kuratko, D. F., \& Covin, J. G. (2008). Corporate Entrepreneurship and Innovation. Thomson Higher Education.

Orel, M. (2019). Coworking environments and digital nomadism: Balancing work and leisure whilst on the move. World Leisure Journal, 61(3), 215-227.

Pearce, I., John, A., Fritz, D. A., \& Davis, P. S. (2010). Entrepreneurial orientation and the performance of religious congregations as predicted by rational choice theory. Entrepreneurship Theory and Practice, 34(1), 219-248.
Pinchot, G., III. (1985). Intrapreneuring: Why you don't have to leave the corporation to become an entrepreneur. Harper \& Row.

Rauch, A., Wiklund, J., Lumpkin, G. T., \& Frese, M. (2009). Entrepreneurial orientation and business performance: An assessment of past research and suggestions for the future. Entrepreneurship Theory and Practice, 33(3), 761-787.

Spinuzzi, C. (2012). Working alone together: Coworking as emergent collaborative activity. Journal of Business and Technical Communication, 26(4), 399-441.

Stopford, J. M., \& Baden-Fuller, C. W. F. (1994). Creating corporate entrepreneurship. Strategic Management Journal, 15(7), 521-536.

Strauss, A., \& Corbin, J. (1998). Basics of qualitative research: Techniques and procedures for developing grounded theory (2 ed.). Sage Publications.

Täuscher, K., Bouncken, R., \& Pesch, R. (2020). Gaining legitimacy by being different: Optimal distinctiveness in crowdfunding platforms. Academy of Management Journal (in press).

Tiberius, V. R., Meike \& Bouncken, R. (2020). Performance analysis and science mapping of institutional entrepreneurship research. Administrative Science (Special Issue Innovation Management and Entrepreneurship) 10(3), 69-90.

Tracey, P., Phillips, N., \& Jarvis, O. (2011). Bridging institutional entrepreneurship and the creation of new organizational forms: A multilevel model. Organization Science, 22(1), 60-80.

Vij, S., \& Bedi, H. (2012). Relationship between entrepreneurial orientation and business performance: A review of literature. The IUP Journal of Business Strategy, 9(3), 17-31.

Waters-Lynch, J., \& Duff, C. (2019). The affective commons of coworking. Human Relations. https://doi. org/10.1177/0018726719894633

Welch, C., Piekkari, R., Plakoyiannaki, E., \& Paavilainen-Mäntymäki, E. (2011). Theorising from case studies: Towards a pluralist future for international business research. Journal of International Business Studies, 42(5), 740-762.

Yin, R. K. (2009). Case study research: Design and Methods. Sage Publications. 